\title{
Settlement of Construction Dispute in Building Bridge through the Indonesian National Arbitration Agency (Bani)
}

\author{
Deny Haspada \\ Langlangbuana University Bandung, Indonesia \\ Corresponding author; denmuter@yahoo.com
}

Received 08 March 2020;

Accepted 16 March 2020;

Published 30 March 2020;

\begin{abstract}
In a construction work contract, legal disputes often occur during the implementation of the construction work contract, because there are achievements that are late and cannot satisfy one of the parties in the contract. Construction disputes have an impact on legal issues that result in time, cost losses and hinder the contribution of the construction sector in economic growth. The growth of the construction market in the era of globalization is also accompanied by high levels of legal disputes. With the issuance of the Law No. 2 of 2017 regarding Construction Services, it is hoped that problems relating to construction disputes will be more quickly resolved.
\end{abstract}

Keywords: Construction Disputes, Buildings, Bridges.

\section{Introduction}

The term 'construction' is absorbed from English, namely Construction. In a technical sense, the term construction is used to describe an activity whose end result is a building / construction that integrates with the land where it is located, whether used as a residence or other means of activity. The construction work activities include buildings, roads, bridges, rail and rail bridges, tunnels, water and drainage buildings, sanitation buildings, airstrips, docks, power plant buildings, transmission, distribution and communication network buildings.

The definition of construction is now clearly regulated in Law No. 2 of 2017 concerning Construction Services, so that the word construction has become one of the juridical terms in Indonesia when it concerns the interests of people and legal entities moreover the understanding is regulated in statutory regulations. Building construction for a standard one-story building often does not use a construction expert, but rather directly through a builder with the design as well as the order giver himself.

When building a building with the help of a building expert, of course it requires the services of the building expert. Construction work through a building expert both for architectural design and for building construction is through construction services because basically there are more acts of assisting construction work, hence it is commonly referred to as construction services in accordance with those stipulated in the law.

In accordance with the law on construction services, when there is a dispute or dispute in the construction sector, the parties concerned must always pay attention to Article 88 of Law Number 2 of 2017, concerning construction services because in that article it regulates the way of dispute resolution, the parties disputes can solve their problems through various legal options not only through the District Court, but there are various options including mediation, conciliation and arbitration.

Construction Services Activities are related to supporting social and economic social activities from various sectors because it is a complex business activity involving many interests both the Government, business actors, foreign investors, service users to each other have different interests. Viewed from the legal side, this sector contains its own complexities because it intersects with many legal regulations. For example, the construction of a Toll Road will be in contact with construction services regulations, environmental regulations, land regulations, investment regulations, labor regulations, tax regulations, banking regulations, and other regulations. Of the many relevant legal regulations, this paper focuses on Law No. 2 of 2017 concerning Construction Services (2017 Construction Services Act).

Indonesia's construction sector is in transition to the rule of law because at the same time, Indonesia is faced with the phenomenon of equitable development. The current government is aggressively building infrastructure projects to remote areas, so it is demanded to make more comprehensive rules. His goal is to provide connectivity networks in all regions and eliminate economic gaps in all regions of Indonesia.

Therefore the Government to realize its ideals was made Presidential Regulation No. 58 of 2017 concerning amendments to Presidential Regulation No. 3 of 2016 concerning the Acceleration of the Implementation of the National Strategic Project which contains 245 National Strategic Projects (PSN) plus two programs, namely: the electricity program and the aircraft industry program.

Equitable development of facilities and infrastructure will have an impact on other sectors, including food security in each region, meeting national electricity and energy needs, improving education and health facilities, adequate access to the transportation of goods and services, and increasing tourism 
attractiveness. Community participation that also invests in development will greatly assist in further development including labor absorption, investment, the number of infrastructure and building projects, reciprocal relationships with supporting sectors, even as a facilitator in the movement and growth of goods and services.

Infrastructure development especially bridges will provide new opportunities for people who were previously isolated to be facilitated in the transportation sector will bring fresh air to the country's economy, but the government should be aware of this phenomenon. The intensity of development on a large scale has the potential to trigger an increase in disputes. However, construction disputes (construction dispute) are still a serious problem in several countries. Construction disputes always cause harm to the parties to the dispute, with disputes, the popularity and relations between parties to the conflict, will worsen, especially when the dispute reaches the level of litigation where the level of tension has reached its highest point, compared to other settlement methods.

These concerns can at least be minimized after the issuance of the 2017 Construction Services Law. In addition to supporting business activities in the construction sector, this legal instrument is also expected to facilitate the resolution of construction disputes in Indonesia. Therefore, the rules contained in the 2017 Construction Services Law must be interpreted consistently and integrative. Do not result in misperceptions for the legislators when formulating regulations for the implementation of the 2017 Construction Services Law. Based on the background description above, the legal issues in this paper are formulated in the form of Legal Questions, namely: "How to Settle Disputes on Bridge Construction through the Indonesian National Arbitration Board ?" This legal analysis aims to discover the philosophy and mechanism of dispute resolution carried out in the 2017 Construction Services Law. Do not let the uncertainty caused by conflicting legal rules or unclear due to the formulation of multi-interpretative articles influence the perception of the legislators when formulating the regulations for the implementation of the 2017 Construction Services Law. The answer to this question was obtained through a legal research process.

Because the demands of scholarship, the authors use one of the recognized research methods in the field of law, the Normative Juridical Research method. This method is a library research or research on secondary data. This method is also seen as a study of positive legal norms. Secondary data examined include primary legal materials and secondary legal materials. This study uses primary legal material that was investigated mainly by the Construction Services Act 2017 and other relevant regulations. The literature used for secondary legal materials used includes books and scientific articles in the field of law, both print and digital, which then the data is studied carefully, critically analyzed and finally presented in the form of scientific writing to answer legal issues in this study.

\section{Agreement of the Parties.}

Basically, a construction contract begins with an agreement between the parties between the giver of the order and the recipient of the order to do something that has been agreed upon. Therefore, the agreement between the parties must fulfill the elements of a work contract agreed by the parties, both parties between person and person, person with legal entity, person with state, state, with legal entity, state and country etc. . In Indonesia, of course the contractual agreement that applies is to use Indonesian law and use Indonesian but sometimes foreign investors who insist on wanting to use the law of their country, therefore in this case the Indonesian party must also be clever in lobbying or applying provisions so that the provisions of prevailing in Indonesia can lure foreign investors.

A construction project work contract becomes an agreement that must be fulfilled because there are agreed interests. Because there is a demand from service users on the other hand, service providers also participate actively offering their services. In the Construction Services law defines the Service User as the owner or employer who uses the Construction Services service, while the Service Provider is the Construction Services service provider. Construction Services are "construction consultancy services and / or construction works". This definition contains two different service concepts in the construction sector, namely "consulting services" and "employment services". In a construction contract, of course, it must meet the legal requirements of an agreement which in general can refer to Article 1320 of the Civil Code. But the Construction Services Act also regulates what is referred to as a "Construction Work Contract", which is the entire contract document governing the legal relationship between Service Users and Service Providers in the administration of Construction Services. As in Article 1233, one of the Birth Agreements is caused by the Agreement. This provision was formulated in Article 1233 of the Civil Code which states: "Each engagement is born either because of an agreement, either because of the law", meaning that the agreement can be based on the law or made by the parties based on the agreement. Construction Work Contracts as a source of birth of an obligation in the field of Construction Services. The Construction Work Contract is also proof that a contractual relationship has been born. In civil law there are only two types of claims against civil violations, namely Unlawful Acts and Defaults. Violations of contractual relationships include breaches of Defaults. After the enactment of Law Number 2 of 2017 concerning Construction Services in Article 88 the parties have a legal choice to resolve disputes that arise between the parties through mediation, conciliation and arbitration.

Prior to the issuance of the law on construction services, every dispute in the field of construction was resolved through a lawsuit that came in the realm of civilization. No one wants a dispute with other parties in the construction field, but the ideal conditions are difficult to realize because humans are unpredictable creatures. However, disputes still occur in shared life. Disputes arise and result in a number of losses between the parties to the dispute. To anticipate disputes and / or resolve disputes that arise, humans take a variety of ways.

Construction disputes also have their own peculiarities. One of the characteristics that is caused by the existence of "claims". The definition of claims in the construction sector is different from the definition of claims in terms of the general public. In the construction sector, disputes can arise if "claims" are not facilitated properly. In addition, construction disputes can also be caused by the following matters:

a) Unbalanced risk allocation

b) Unclear risk allocation

c) Unrealistic cost, time and quality targets

d) Uncontrollable external events

e) Competition due to culture

f) Unrealistic tender pricing

g) Inappropriate and imperfect contracts

h) Inability / Skill of project participants

i) Lack of professionalism

j) Clients don't get the right information so they are skeptical

k) Providing unrealistic information expectation by contractors 
The above description only presents a small cause of disputes in the construction sector. The above list can grow again because of the complexity of the construction service sector itself. However, contracts are the main guideline for the parties when working in the field. If the contract planner is not observant, mistaken and unable to facilitate the interests of the parties fairly, the contract will be the main source of dispute in the future. In addition to human quality factors, construction disputes are also influenced by factors outside of human power, such as political, economic and security factors that are unstable, environment (culture), changes in legal regulations and geographical conditions, thus, disputes in the construction sector are caused by two factors, namely human quality factors and factors outside human power.

\section{Alternative Construction Conflict Resolution in Indonesia}

In order to get an accurate picture of the settlement of construction disputes, let's compare the two legal regimes, namely the old law (the Construction Services Act 1999) and the new law (the 2017 Construction Services Act).

Pay close attention, the two laws mandate different philosophies (zeal) and dispute resolution mechanisms. The old rules (Construction Services Act 1999) provide two alternative dispute resolution. This is confirmed in Article 36 point (1) which reads: "Settlement of construction service disputes can be reached through the court or outside the court based on the voluntary choice of the disputing parties." With legal efforts opened to court, decisions made by non-Litigation institutions seem to have lost their fangs. The resulting decision is not final and binding. Litigation institutions seem to be higher than non-Litigation institutions.

However, this employment relationship does not always work as intended. In the implementation of this contract, there are often differences in understanding, disputes and disputes between the parties and then become a legal dispute. Legal disputes in construction work contracts will have an impact on both parties, including additional costs, loss of time and energy and thought. If a dispute occurs, then the dispute resolution must be done to end or resolve the dispute.

If the deliberation does not reach consensus, the new parties then turn to the dispute resolution efforts listed in the Construction Work Contract. If examined, the law limits the efforts to settle disputes stated in the Construction Work Contract. These efforts only include mediation, conciliation, and arbitration. The word "and" is meant as a tiered dispute resolution mechanism, not an alternative choice. This means that the parties cannot directly choose an arbitration institution if the deliberation fails. Arbitration can only be carried out if the construction dispute is not successfully resolved by deliberation, mediation and conciliation. Another change that can be observed is the increase in 'third party' services in the 2017 Construction Services Act. Previously, the old law (the Construction Services Act 1999) stipulated that dispute resolution outside the court (non-Litigation) could use third party services, which included : arbitration services at national and international arbitration or ad-hoc arbitration institutions, mediator services at mediation institutions, conciliator services at conciliation institutions and expert appraisal services. To complement the variations of the 'third party', the Dispute Board was also presented in the 2017 Construction Services Act. The law states that the Dispute Board is a team formed based on the agreement of the parties since the Construction Services binding to prevent and mediate disputes that occur in in the implementation of Construction Work Contracts.

\section{Conclusion}

Construction Conflict Settlement in Indonesia formally still does not have an official reference, but in order to fill the legal vacuum and so that there is legal certainty from the disputing parties, the parties may submit themselves obediently and obediently to the choice of law they will choose. Civil Procedure Law can also be called formal civil law because it regulates the process of case resolution through a court that is formally recognized as valid under the law.

Formal civil law aims to protect the interests of every member of the community. These interests are civil rights and obligations stipulated in material civil law. Thus, formal civil law is the entire rule of law that determines and regulates how to implement civil rights and obligations as stipulated in material civil law. Broadly speaking, dispute resolution is divided into two mechanisms, namely dispute resolution through the courts (Litigation) and through institutions / institutions outside the court (non-litigation).

Non-Litigation mechanism prioritizes procedural law procedures that have been specifically regulated outside general civil procedural law. For example Law No. 30 of 1999 concerning Arbitration and Alternative Dispute Resolution (Arbitration Law \& ADR) contains civil procedural law that specifically regulates dispute resolution outside the court institution. When examined, in the law there are several articles that contain aspects of formal civil law. One of them is an article which specifically regulates the settlement of construction disputes. Thus, the 2017 Construction Services Act is one of the special rules in the realm of civil procedural law. Consequently, in the event of a construction dispute, the provisions of dispute resolution that have been regulated in the 2017 Construction Services Act will take precedence over the effectiveness of the general civil procedural law.

However, the resolution of business disputes in the era of globalization with the characteristics of "moving quickly", demands ways that are "informal procedure and be put in motion quickly". In addition, with regard to cases in the Judiciary, it is necessary to pay attention to the words of Abraham Lincoln which more or less contain meaning: "in every case there really is no victory" All lost Only one person won, namely the legal advisor who received payment from the litigants. In the Indonesian perspective, the phrase is parallel with the phrase or the saying "lose to ash, win into charcoal".

The stages of dispute resolution according to Law No. 2/2017 are:

1. The parties to the dispute first hold a deliberation to reach consensus;

2. If the meeting is not reached, the dispute resolution will be adjusted based on the construction work contract;

3. If the dispute resolution is stated in the contract, then the dispute resolution is carried out through the following stages:

4. Mediation;

5. Conciliation, and;

6. Arbitration

7. If the dispute resolution is not included in the construction work contract, the parties to the dispute make the chosen settlement procedure 
The mechanism of settlement of construction disputes between the parties emphasizes more on the resolution outside the court. This is inseparable from the benefits of arbitration and alternative dispute resolution, where at least there are several advantages, namely:

First, the secrecy of the dispute is maintained. Confidentiality is an advantage that can be obtained when using a line outside the court. This is caused by the process until the dispute resolution decision is not made public. This advantage will certainly have implications for the relationship between the parties to the dispute remains good, so that the continuity of work can still be continued.

Second, the dispute is decided by a mediator (mediator, conciliator, arbitrator) who understands the construction field. This is because the parties to the dispute can freely choose the mediator who will decide or give advice regarding the dispute that is happening. This means that the parties can choose an intermediary who has knowledge of construction. This is inseparable from the nature of the construction dispute which is technical in nature, so that the mediating party can decide or give an appropriate recommendation.

Third, the period is relatively short. Arbitration and Alternative Dispute Resolution has the advantage over time in dispute resolution. That is, dispute resolution can be resolved more quickly than settlement through the court. This will certainly have implications for the certainty that will be received by the parties to the dispute, such as: certainty over the continuity of work, payment of work. Conditions according to the needs of the parties where the dispute can be resolved by not threatening the continuation of work and good relations between the parties. On the contrary, the services of arbitrators, mediators, conciliators will only be needed after construction disputes arise.

\section{References}

[1] Abdulkadir Muhammad, Indonesian Civil Procedure Law, Bandung: PT Citra Aditya Bakti, 2015.

[2] Gatot Soemartono,. Arbitration and Mediation in Indonesia. Jakarta: PT Gramedia Pustaka Utama, 2006

[3] Jimly.Asshiddiqie, Regarding the law, Jakarta: Rajawali Pers, 2011.

[4] Nazarkhan Yasin, Knowing Construction Claims \& Construction Dispute Resolution (Second Book of Construction Law Series). Jakarta: PT Gramedia Pustaka Utama, 2004.

[5] Nurun Ainuddin, Pattern of Compensation Settlement for Compensation in the Construction Services Construction Agreement, Engineering Journal, vol. 13, No. 1, Universitas Mataram (June 2012).

[6] Priatna Abdurrasyid, Arbitration \& Alternative Dispute Resolution (An Introduction), Jakarta: Fikahati Aneska in cooperation with BANI, 2002.

[7] Republic of Indonesia statistical center, Construction in Figures 2017, Jakarta: BPS, 2017.

[8] Retnowulan Sutantio dan Iskandar Oeripkartawinata, Civil Procedure Law in Theory and Practice, 11th, Bandung: CV Mandar Maju, 2009.

[9] Soerjono Soekanto, Normative Legal Research - A Short Review, Jakarta: Rajawali Pers, 1990.

[10] Sunaryati Hartono, Legal Research in Indonesia at the End of the 20th Century, Bandung: Alumni, 1994. 